\title{
Experimental behaviour of threaded steel rods glued into high- density hardwood
}

\author{
J. Estévez Cimadevila, J.A. Vázquez Rodríguez, M.D. Otero Chans \\ Department of Construction Technology, Escuela Técnica Superior de Arquitectura, University of A Coruña, Spain
}

\begin{abstract}
This paper shows the test results for resin-glued steel rods under axial load. These steel rods are glued into timber using a two-component Hilti HIT-RE 500 resin. The timber species used in the tests was Tali. Three different anchorage lengths were combined withtwo rod diameters and two resin thicknesses. The test failure values have been compared to some available theoretical formulations. The formulation in the Eurocode 5 informative appendix is one of these. The results show a significant difference between the theoretical andthe test strength values of these joints. This is mainly due to the fact that the theoretical formulations are based on tests on lower density softwoods. Therefore, the research demands more analytical-experimental work in order to achieve more precise theoretical models.
\end{abstract}

Keywords

Joint design; Adhesives for wood; Destructive testing

\section{Introduction}

Our team has been researching for a long time on space frames. Timber space frames are a particular aspect of this research. Special attention has been paid to the use of hollow sections in the making of this type of structure(Fig. 1) [1,2]. Several patents are the outcome of our pioneering work in this field.

A Coruña University commissioned the design of the roof structure for a sports hall on the Zapateira Campus(Fig. 2) [3,4]. The project became the first built application of the research. The main aim was to span over this hall with a stackable modular space frame made up with hollow timber sections.

Achieving an efficient transmission of loads in the bar node is one of the main problems of this type of structures. The use of hollow sections increases even more this problem. 


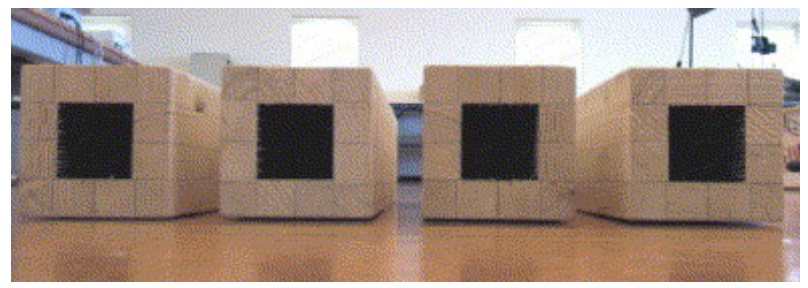

Fig. 1. View of the space frame hollow sections. The outer cross-section was $120 \times 120 \mathrm{~mm}$, and the hollow cross-section $60 \times 60 \mathrm{~mm}$.

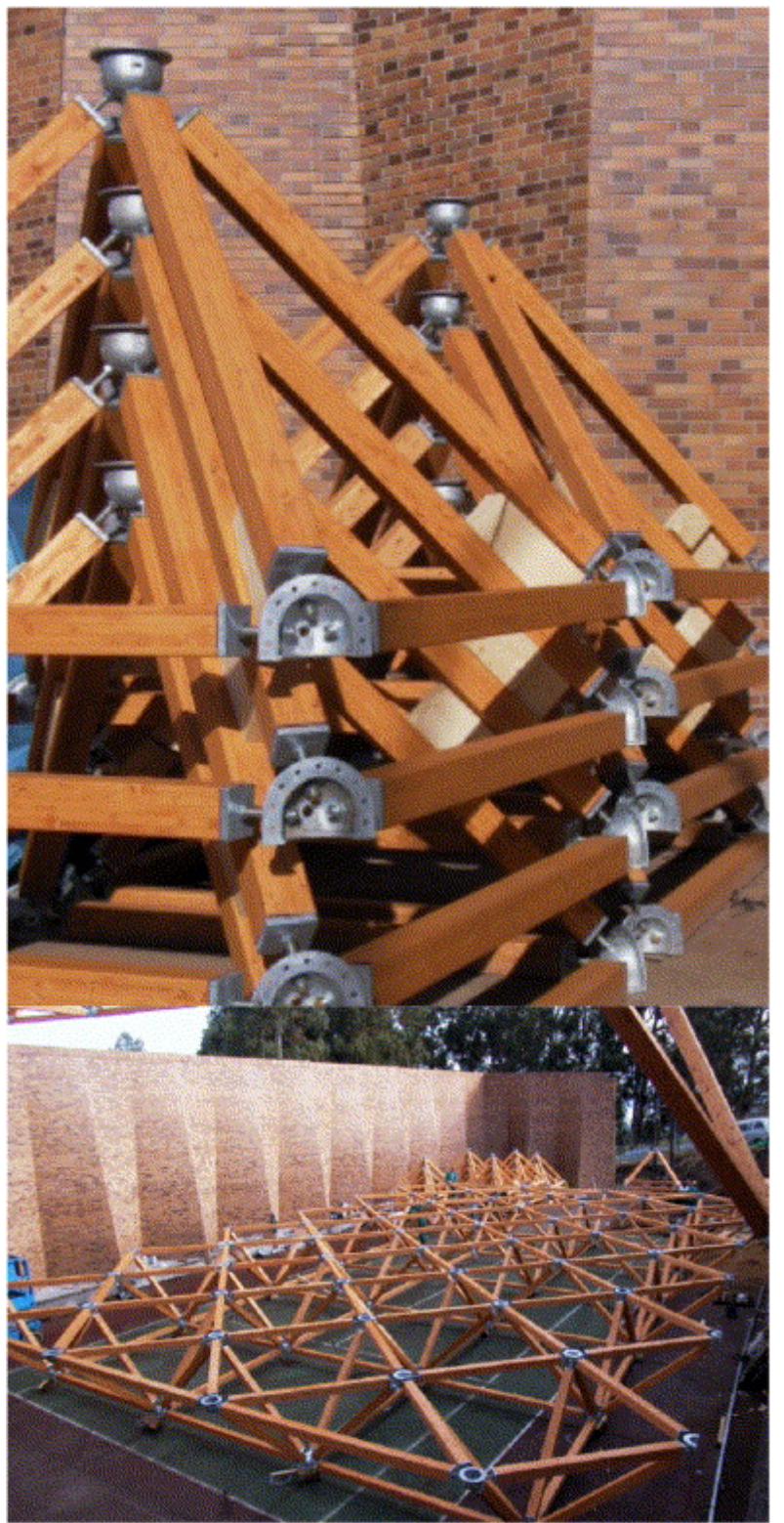

Fig. 2. Stacked space frame modules and view of stacked modules of the space frame before its assembling.

Sports hall. Campus “A Zapateira”. A Coruña. Spain. 
The design solution for the bar end connection with the steel node involves gluing solid timber sections of Elondo or Tali (Erythrophleum ivorense).

Threaded steel rods (either 24 or 27 mm diameter) are then embedded into the sawn timber and glued with a two-component Hilti HIT-RE 500 epoxy resin (epoxidic bisphenol A/F and poliamid alifatic bases, both with inorganic filling).

Given the influence of the efficiency of this connector onthe behaviour of the structure, we decided to supplement the theoretical calculations with experimental analysis. This was the main aim of this article.

\section{Test set-up}

The test samples are made with sawn timber sections of Tali, like timber used in joint nodes of the roof structure, achieving an average density of $856.36 \mathrm{~kg} / \mathrm{m}^{3}$, which corresponds to the 5 th percentile. The timber moisture atthe time of bonding is always lower than $12 \%$. Galvanized threaded steel bars of grade 8.8 (with a yield strength of $f_{\mathrm{y}}=640 \mathrm{~N} / \mathrm{mm}^{2}$ and minimum tensile strength of $f_{\mathrm{u}}=800 \mathrm{~N} / \mathrm{mm}^{2}$ ) have been used. Rod surface was nottreated before bonding, because this is not a usual practicein normal construction. The adhesive was the same asthe one used in the construction of the space frame; Hilti HITRE 500 was made of two components: epoxidicbisphenol A/F and poliamid alifatic bases, both withinorganic filling.

The cross-section dimensions ('a'and'b') of the testsamples correspond to $75 \mathrm{~mm}$ in order to address the constructive needs of the space frame hollow sections (Figs. 2 and 3). Also, the chosen dimensional value is approximately equivalent to three times the rod diameter $(\varnothing)$, which corresponds to the minimum design dimensions established by Riberholt [5-7].

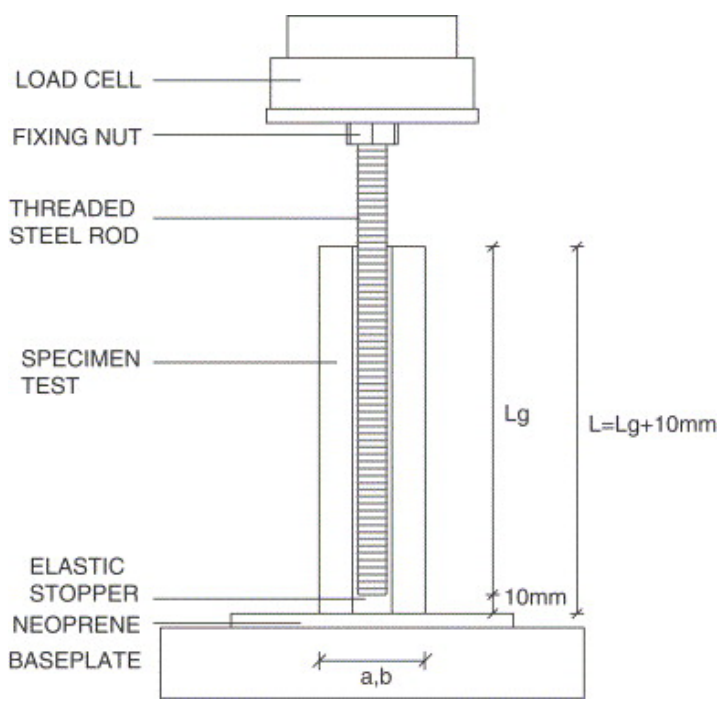

Fig. 3. Test set-up detail.

Two bar diameters (M24 and M27), three glued anchorage lengths (200, 250 and $300 \mathrm{~mm}$.) and two adhesive thicknesses ( 1 and $3 \mathrm{~mm}$.) have been studied. The results were 12 series of test samples. The dimensionsof these samples are shown in detail in Table 1. 
Table 1. Dimensional characteristics of the tested samples

\begin{tabular}{|c|c|c|c|c|c|}
\hline & $\begin{array}{l}\text { Adhesive } \\
\text { thickness } \\
\text { e (mm) }\end{array}$ & $\begin{array}{l}\text { Hole } \\
\text { diameter } \\
\emptyset+2 \mathrm{e}(\mathrm{mm})\end{array}$ & $\begin{array}{l}\text { Glued-in } \\
\text { length } \\
\text { Lg }(\mathrm{mm})\end{array}$ & $\begin{array}{l}\text { Sample } \\
\text { dimensions } \\
\mathrm{a} \times \mathrm{b} \times \mathrm{L}(\mathrm{mm})\end{array}$ & $\begin{array}{l}\text { Rod } \\
\text { diameter } \\
\varnothing(\mathrm{mm})\end{array}$ \\
\hline Series 1 & 1 & 26 & 200 & $75 \times 75 \times 210$ & 24 \\
\hline Series 2 & 3 & 30 & & & \\
\hline Series 3 & 1 & 26 & 250 & $75 \times 75 \times 260$ & \\
\hline Series 4 & 3 & 30 & & & \\
\hline Series 5 & 1 & 26 & 300 & $75 \times 75 \times 310$ & \\
\hline Series 6 & 3 & 30 & & & \\
\hline Series 7 & 1 & 29 & 200 & $75 \times 75 \times 210$ & 27 \\
\hline Series 8 & 3 & 33 & & & \\
\hline Series 9 & 1 & 29 & 250 & $75 \times 75 \times 260$ & \\
\hline Series 10 & 3 & 33 & & & \\
\hline Series 11 & 1 & 29 & 300 & $75 \times 75 \times 310$ & \\
\hline Series 12 & 3 & 33 & & & \\
\hline
\end{tabular}

Three test samples were made for each series. The experimental analysis illustrated in Fig. 11 shows how, except for series 10 and 12, there exists an agreement between the obtained results for each series. Therefore, increasing the number or tested elements was not considered necessary.

The test sample was longitudinally drilled with an auger drill to the centre of the section. The lower end of the sample was then closed with a $10 \mathrm{~mm}$ thick piece of elastic material (elastic stopper) (Fig. 3). The adhesive was blown to fill the drilled cavity with a mixing gun. Afterwards, the threaded bars were inserted manually by continuous pressing and rotating (Fig. 4). The particular design of the test sample has been chosen in order to enable the test to be carried out in a INSTRON mod. 8805, $1000 \mathrm{kN}$ onesided pull-compression universal dynamic press (Fig. 5). The elastic stopper at the lower end of the test sample allows the threaded bar to glide down when it reaches its load limit. For test reliability purposes, the rod-exposed end was fastened to the load cell by means of a nut. Also, the test sample was placed on the base plate with a $3 \mathrm{~mm}$ thick neoprene sheet in between in order to take the imperfections of the support.

The one-sided-push compression tests were carried out increasing the load with a constant displacement. The failure value was reached in $5 \pm 2 \mathrm{~min}$. These are short-time-length tests. Long-timelength tests should be carried out in the future in order to look at the performance of the adhesive in relation to the load imposing time.

The INSTRON test machine has an electronic device that controls the displacement of the load cell. It also interprets the results with a computer system that gives the digitalized relationship between load, displacement and test time-length. In the graphic representation of results illustrated in Fig. 11, the obtained displacements were reduced considering the elastic shortening value of rods. 


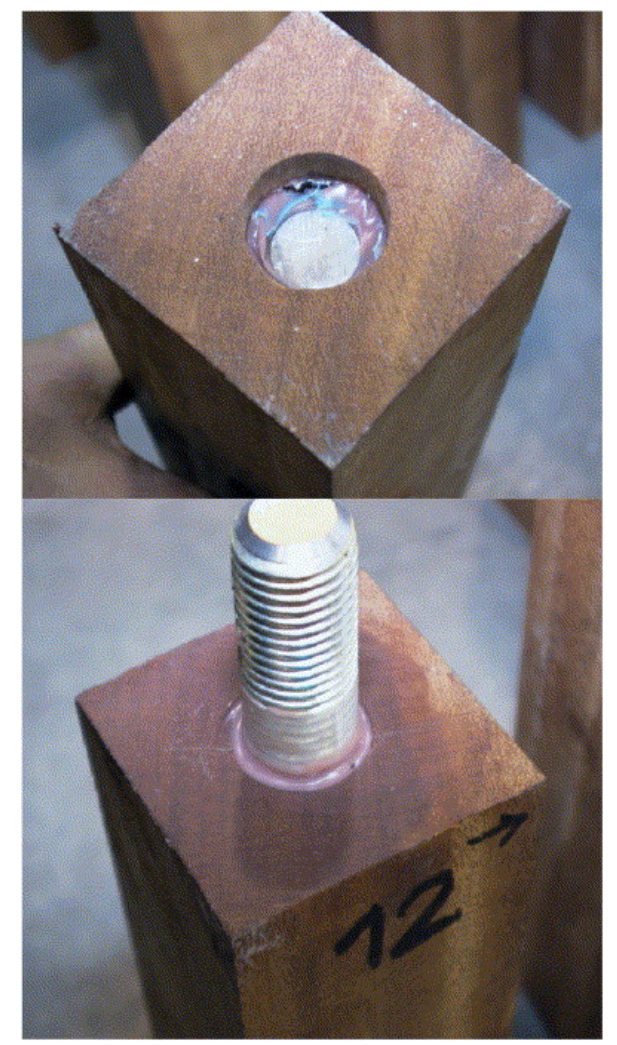

Fig. 4. View of the lower and upper end of the test sample.

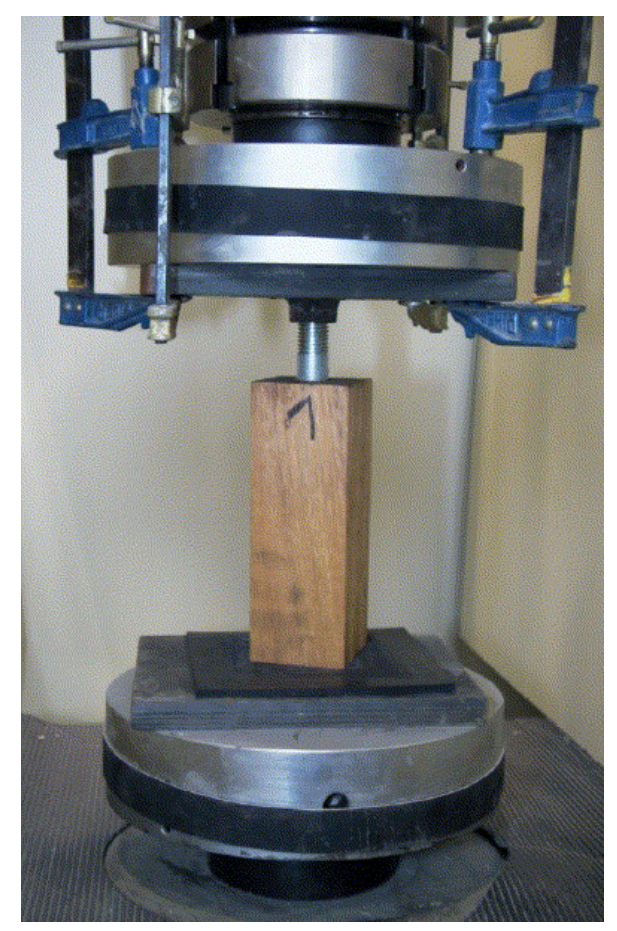

Fig. 5. View of the test set-up. 


\section{Results}

The achieved failure load results are listed in Table 2. Characteristic (corresponding to the 5th percentile), average and maximum failure values are shown for each series (Table 2).

The last two columns of the previous table show the axial load values resulting from the application of Riberholt [5], [6] expressions and the data taken from the Eurocode 5 informative appendix in accordance with

Riberholt: $\quad R_{\mathrm{ax}, \mathrm{k}}=f_{\mathrm{ws}} p k d \sqrt{ } L_{\mathrm{g}}$

Eurocode5: $R_{\mathrm{ax}, \mathrm{k}}=\pi d_{\text {equ }} L_{\mathrm{g}} f_{\mathrm{vk}}$

$$
f_{\mathrm{vk}}=0,8 \times 10^{-3} p k^{1,5} d^{-0,2}
$$

where $R_{\mathrm{ax}, \mathrm{k}}$ is the characteristic axial load $(\mathrm{N}), f_{\mathrm{ws}}$ and the resistance parameter $\left(\mathrm{N} / \mathrm{mm}^{1,5}\right)$. Epoxi-type adhesives take the value of $0.52 ; f_{\mathrm{vk}}$, withdrawal strength $\left(\mathrm{N} / \mathrm{mm}^{2}\right) ; d$, hole diameter $(\mathrm{mm}) ; d_{\text {equ }}$, lowest of hole diameter $(\mathrm{mm})$ and 1.25 times the diameter of the bar $(\mathrm{mm}) ; L_{\mathrm{g}}$, glued-in anchorage length $(\mathrm{mm}) ; \rho_{\mathrm{k}}$, timber average density $\left(\mathrm{Kg} / \mathrm{m}^{3}\right)$.

Table 2.

$\begin{array}{lllll}\text { Failure load. } & \text { Failure load. } & \text { Failure load. } & \text { Characteristic } & \text { Characteristic } \\ \text { Maximum } & \text { Average } & \text { Characteristic } & \text { value of axial } & \text { value of axial } \\ \text { value }(\mathrm{kN}) & \text { value }(\mathrm{kN}) & \text { value }(\mathrm{kN}) & \text { load Riberholt } & \text { load EC-5 (KN) }\end{array}$

\begin{tabular}{|c|c|c|c|c|c|}
\hline \multirow{2}{*}{\multicolumn{6}{|c|}{ (a) Failure values obtained in the tests and analytical values }} \\
\hline & & & & & \\
\hline Series 1 & 158.20 & 152.99 & 142.49 & 165.46 & 173.40 \\
\hline Series 2 & 197.82 & 184.65 & 169.40 & 190.91 & 194.43 \\
\hline Series 3 & 177.42 & 159.58 & 135.69 & 184.99 & 216.75 \\
\hline Series 4 & 213.87 & 203.05 & 191.05 & 213.45 & 243.04 \\
\hline Series 5 & 186.05 & 169.63 & 151.41 & 202.64 & 260.10 \\
\hline Series 6 & 219.87 & 214.00 & 203.61 & 233.82 & 291.64 \\
\hline Series 7 & 193.82 & 160.84 & 123.43 & 184.55 & 189.23 \\
\hline Series 8 & 249.24 & 219.72 & 172.81 & 210.00 & 209.83 \\
\hline Series 9 & 258.67 & 248.21 & 234.73 & 206.33 & 236.53 \\
\hline Series 10 & 290.88 & 248.93 & 203.71 & 234.79 & 262.29 \\
\hline Series 11 & 275.95 & 262.77 & 241.12 & 226.03 & 283.84 \\
\hline \multirow[t]{2}{*}{ Series 12} & 299.30 & 247.88 & 190.67 & 257.20 & 314.75 \\
\hline & $\begin{array}{l}\text { Failure load. } \\
\text { Average } \\
\text { value }(\mathrm{kN})\end{array}$ & $\begin{array}{l}\text { Average shear } \\
\text { stress } \\
\text { adhesive/rod } \\
\text { interface (MPa) }\end{array}$ & $\begin{array}{l}\text { Average shear } \\
\text { stress } \\
\text { adhesive/timber } \\
\text { interface (MPa) }\end{array}$ & $\begin{array}{l}\text { Adhesive } \\
\text { thickness } \\
\mathrm{e}(\mathrm{mm})\end{array}$ & $\begin{array}{l}\text { Failure } \\
\text { mode }\end{array}$ \\
\hline \multicolumn{6}{|c|}{ (b) Average shear stresses } \\
\hline Series 1 & 152.99 & 10.15 & 9.36 & 1 & \\
\hline Series 2 & 184.65 & 12.24 & 9.79 & 3 & \\
\hline Series 3 & 159.58 & 8.47 & 7.81 & 1 & \\
\hline Series 4 & 203.05 & 10.77 & 8.62 & 3 & \\
\hline Series 5 & 169.63 & 7.50 & 6.92 & 1 & \\
\hline Series 6 & 214.00 & 9.46 & 7.57 & 3 & \\
\hline Series 7 & 160.84 & 9.48 & 8.83 & 1 & \\
\hline Series 8 & 219.72 & 12.95 & 10.60 & 3 & \\
\hline Series 9 & 248.21 & 11.70 & 10.89 & 1 & \\
\hline Series 10 & 248.93 & 11.74 & 9.60 & 3 & \\
\hline Series 11 & 262.77 & 10.33 & 9.61 & 1 & \\
\hline Series 12 & 247.88 & 9.74 & 7.97 & 3 & \\
\hline
\end{tabular}

Table 2 and Fig. 6 show how the obtained failure values are generally lower than the ones achieved with analytical formulae. We consider that one of the main reasons that could explain this difference is the type of timber used in the tests. 


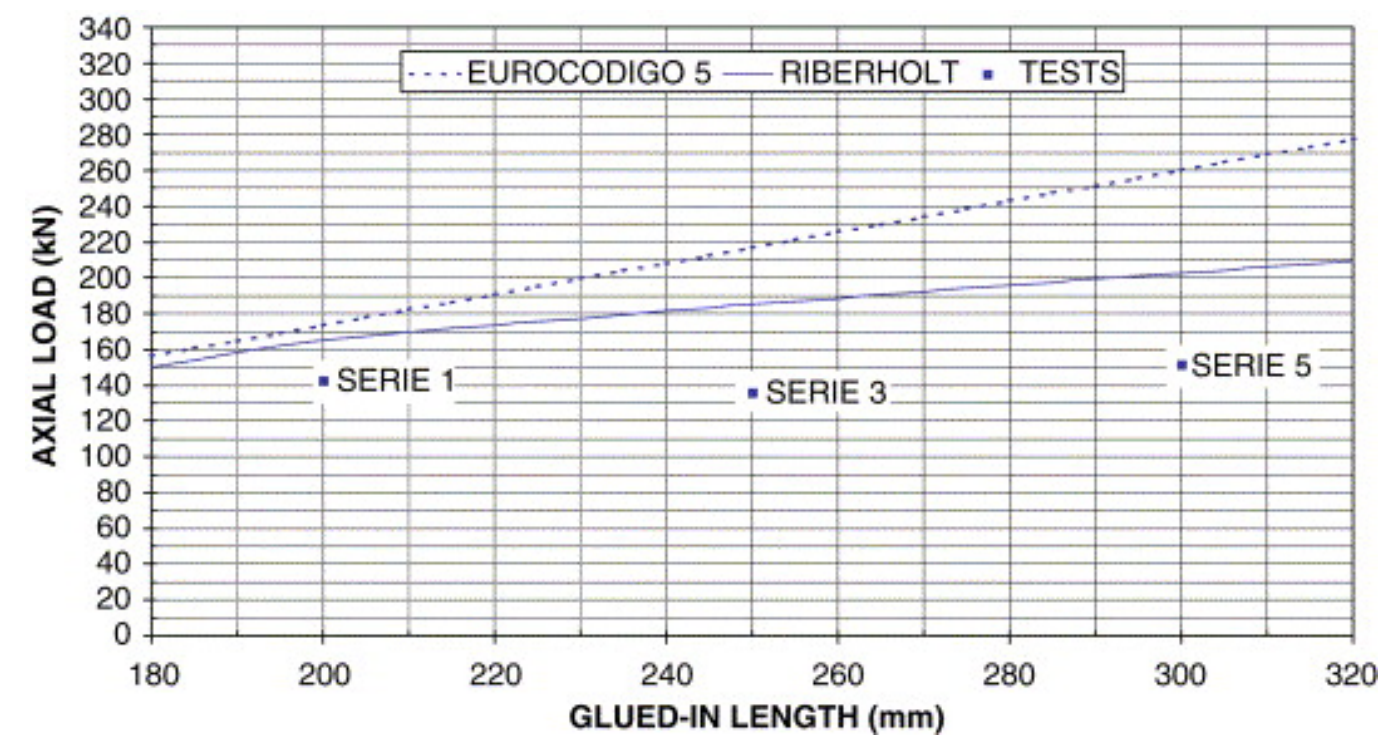

Fig. 6. Comparison of axial load predictions calculated with Riberholt and EC5 formulas and test results (for a deq=26 mm).

The majority of the tests carried out to date (from which current analytical formulae are obtained) have been using softwood test samples. The average density of softwood is much lower than the raw density of the timber used in the test described here.

The average density of the tested samples was $911 \mathrm{~kg} / \mathrm{m}^{3}$. This value would correspond approximately to a strength grade of D60 in the case of hardwood. Also, and due to the low dispersion of test values, the obtained characteristic density is even $20 \%$ higher than the one of the mentioned strength grade (865.36 $\mathrm{kg} / \mathrm{m}^{3}$ in comparison with $700 \mathrm{~kg} / \mathrm{m}^{3}$, which corresponds to the characteristic density of strength grade D60). The mechanical properties of the timber were according to those of the strength class of the EC5.

The fact that no similar tests have been carried out with species of resinous timber brings up the question of how this element can affect the hardening and subsequent performance of the glued joint.

Another factor that could explain the different results is the geometrical configuration of the load application on the samples. In this test, the rod axial load is transmitted to a test sample of freestanding timber. However, the support conditions of the test samples in many of the carried out tests restrain the timber to some degree. And this situation can favour the strength of the timber under the imposed axial load.

Finally, the small distance between the threaded rod and the sample edges could have influenced the strength in a negative way. Although, the major percentage of failure was by shear stress at the interface timber/adhesive. Samples with a longer embedded length were affected by splitting of the timber.

The following illustrations show three different failure values. These were obtained from the tests and depend on the different effects of each parameter:

- adherence failure between the adhesive and the timber (Fig. 7);

- timber splitting (Fig. 8) and;

- failure of the timber adjacent to the glued joint line (Fig. 9). 


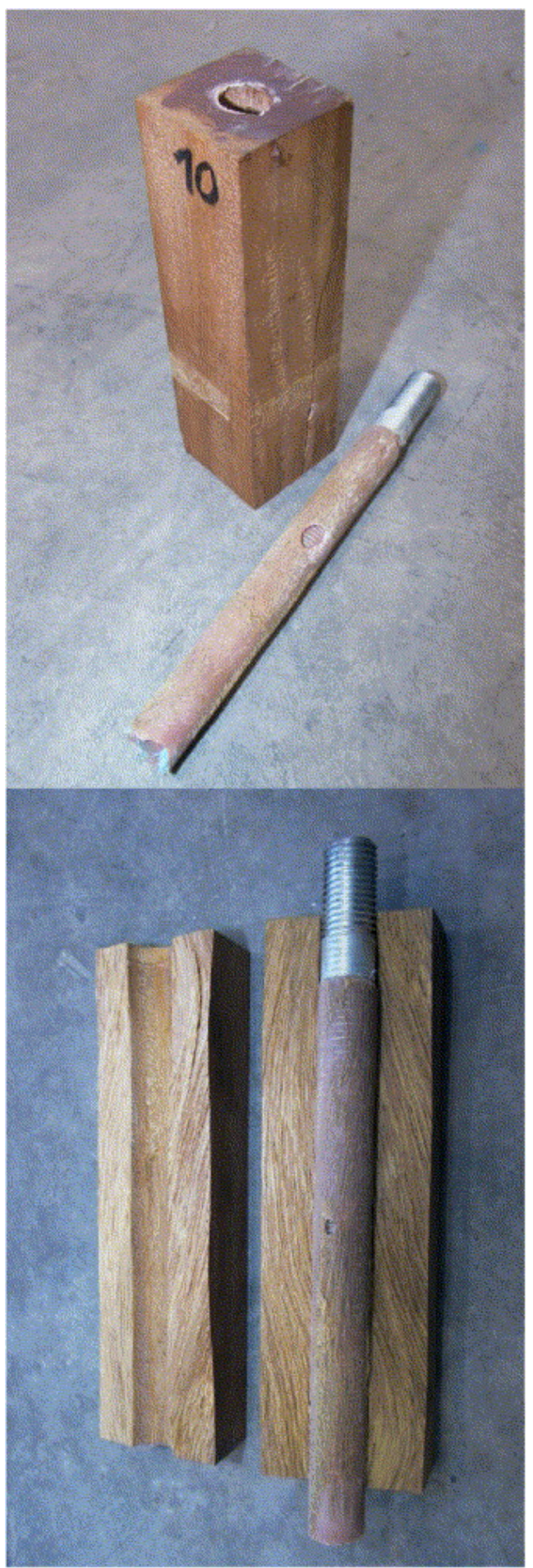

Fig. 7. Examples of adherence failure between the steel rod and the timber. There are also bubbles that sometimes appear in the adhesive. 


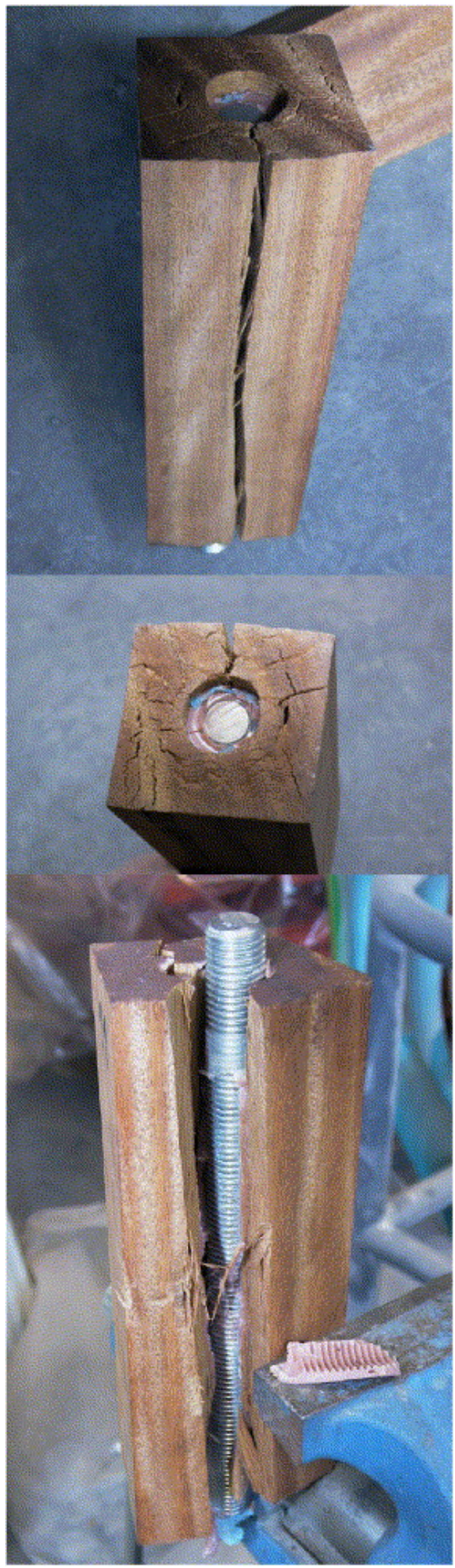

Fig. 8. Examples of the type of failure characterized by the timber section failure. 


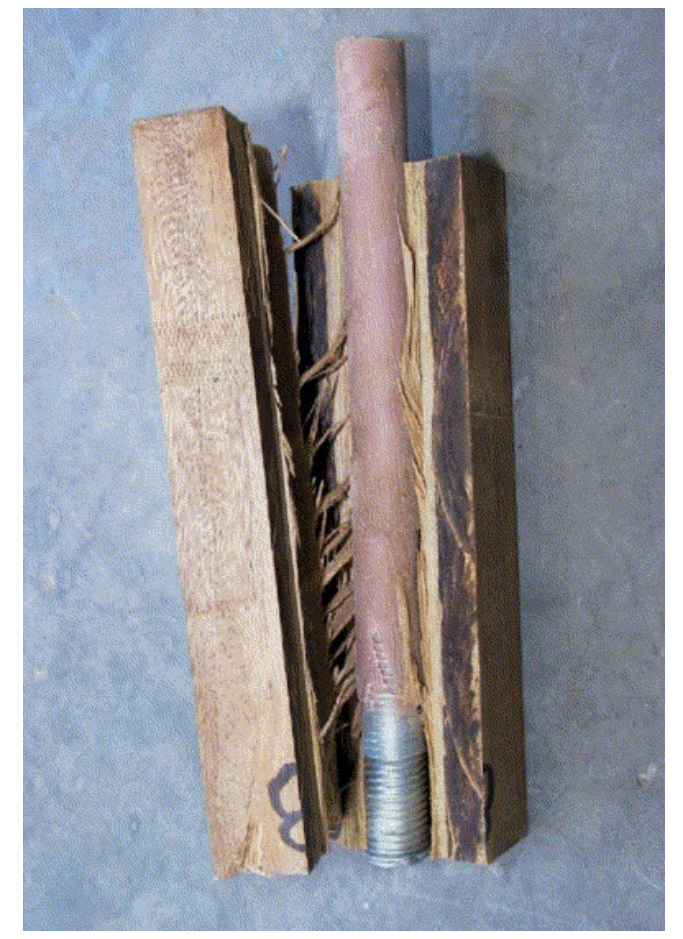

Fig. 9. Failure of timber adjacent to the glued line.

In order to assess the possible effect of each parameter on the achieved failure load values, we compared the obtained average values for each series (as described in Table 1).

\subsection{Variation in glue thicknesses}

Samples with two different glue thicknesses (1 and $3 \mathrm{~mm}$, respectively) have been tested. The dimensional characteristics of each series are shown in Table 1. The bar diagram in Fig. 10 indicates the achieved failure values for each test sample series. Those series among which the only varying parameter is the glue thickness are compared in groups of two. The mentioned illustration shows how, generally, the series with a higher glue thickness achieve higher failure load values. This is not applicable to series 912, because the applied load had reached a high enough value to cause timber failure before the joint used all its potential strength. The increase in the failure load value for the test samples with a higher glue thickness is more significant in the series with a $24 \mathrm{~mm}$ rod diameter (series 1-6). On the other hand, if we compare the axial load/displacement graphs (Fig. 11), we will see how the increase in adhesive thickness results in a more ductile failure. This is not shown in series with a bigger rod diameter.

\subsection{Variation in rod diameters}

Two nominal rod diameters $(24$ and $27 \mathrm{~mm}$ ) were used in the tests. Fig. 12 compares the average failure values for each series and shows how, in all cases, increasing the rod diameter (and therefore the contact surface between steel and adhesive) involves an increase in the test samples' failure load.

Comparing the load/displacement curves for a $3 \mathrm{~mm}$ glue thickness, we see how 24 and $27 \mathrm{~mm}$ rod joints behave differently. For a $27 \mathrm{~mm}$ rod diameter, $3 \mathrm{~mm}$ thick glue series show more correspondence between displacement and load. 


\subsection{Variation in glued anchor length}

Test samples with 200, 250 and $300 \mathrm{~mm}$ anchorage lengths were used in the tests. Fig. 13 shows the obtained average failure values for each series, and compares those groups where the anchor length is the only varying parameter. The numerical expressions that calculate the load capacity of this type of joint (Riberholt and Eurocode 5) consider this parameter as a determining factor. Despite this fact, the tests carried out did not achieve any significant results about that. This shows the need to increase the tests on glued-anchor joints in high-density resinous timber.

In a high percentage of the tests carried out the timber early failure prevents the joint from using its full resistant capacity.

\section{Conclusions}

Several series of samples have been tested. The test samples were made with threaded steel rods glued into Elondo timber (Erythrphleum ivorense). The rods were glued to one of the timber section ends, using a two-component epoxy-base adhesive.

The test samples were made varying the following parameters: glued anchorage length, rod diameter and glue thickness.

The samples have been tested under compressive axial load using a hydraulic press. The obtained results were compared to existing theoretical formulations. These formulations include the one in the EC5 informative appendix. The comparison showed a significant difference between the theoretical predictions and the test results, which were lower than expected.

The difference between the timber used in tests and the timber considered in theoretical formulations appears to be a relevant factor to explain this discrepancy. The geometry of the test sample support on test has also to be considered.

Comparing the results from different series tested, we can see behavioural variations. However, no equivalence has been obtained in order to establish a pattern. This shows the need to increase the test initiative on glued-anchor joints in high-density hardwood.

\section{Acknowledgements}

This research was sponsored by the Ministry of Science and Technology through research project titled "UNIONES METÁLICAS ENCOLADAS CON ADHESIVOS EN BARRAS DE MADERA" (Glued Anchored Timber Joints). The financial support was gratefully acknowledged. 


\section{References}

[1] Estevez Cimadevila FJ, Vázquez Rodríguez JA, Costa Santos S. Geometry of modular space frames assemblies. In: Proceedings of the 5th International Conference on Space Structures, University of Surrey, Guildford, UK. 19-21 August 2002. Ed. Thomas Telford Ltd. London, 2002.p. 1605-30.

[2] Estevez J, Pablos J, Muñiz S, Freire M, Vázquez R, Alvarez J. Double-layer space structures of laminated timber tubular members. In: Proceedings of the 4th international conference on space structures, University of Surrey, Guildford, UK. 5-10 September 1993. Ed. Thomas Telford Services Ltd. London; 1993. p. 563-72.

[3] Estévez Cimadevila FJ, Vázquez Rodríguez J.A.

Spatial truss of hollow bars made of laminated timber supported by walls of reinforced masonry. J Int Assoc Shell Spatial Struct, 45 (1) (2004), p. 144 IASS. ISSN: 0304-3622

[4] Estévez Cimadevila J, Vázquez Rodríguez JA. Edificio sportivo a La Coruña, Spagna. Construire in Laterizio, n.102. Año XVII. Noviembre-Diciembre 2004. Grupo Editoriales Faenza Edotrice S.p.A. Faenza (Ra), 2004.

[5] Riberholt H. Glue Bolts in Glulam. Department of Structural Engineering. Technical University of Denmark. Serie R, No 210, 1986.

[6] Riberholt H. Glued bolts in glulam-Proposal for CIB Code. CIB-W18 Meeting. Parksville, Vancouver Island, Canada. Paper 21-7-2, 1988.

[7] Broughton J.G, Hutchinson A.R. . Adhesive systems for structural connections in timber Int J Adhes Adhes, 21 (3) (2001), pp. 177-186 